\title{
EFFECIENCY OF SOME SUPPLEMENTAL PROTEIN NUTRITION PROCESS IN HONEY BEE COLONIES IN IMPROVED PROPERTIES OF THE HYPOPHARYNGEAL GLANDULAR SECRETION
}

\author{
ZAKARIA, M. E. ${ }^{1}$, NAGLAA E. GHAZALA ${ }^{1}$, E.W. ZIDAN ${ }^{1}$ \\ and SAHAR Y. ABDEL-AZIZ ${ }^{2}$ \\ 1. Dept. Of Apiculture, Plant Protection Research Institute, ARC, Giza \\ 2. Dept. of Economic Entomology and Pesticides, Fac. of Agric. Cairo Univ.,
}

(Manuscript received 5 June 2016)

\begin{abstract}
Q uality of the Royal jelly (RJ) is a reflection of the hypopharyngeal glandular (HG) physiological state. Faraway it depends on the feeding protein and lipids qualitative during and after bee workers maturation. Effect of sustain honey bee colonies by some nutrition process on the (HG) secretion were investigated using HPLC analysis. Honey bee colonies fed one of the 4 treatments (Brewer's Yeast, Soybean flour, Date palm pollen (Phoenix dactylifera) and Pollen grains from other plants); further control treatment. The results indicated presence a clear amelioration in the RJ quality phenols. 1-The tested Benzoic phenol with Date palm pollen treatment recorded the lowest concentration $(2.65 \mathrm{mg} / 100 \mathrm{~g})$ in comparable to control one $(6.88 \mathrm{mg} / 100 \mathrm{~g})$ and lower than others, that is important for public health. 2- The Caffeine phenol restricted the highest record with the pollen grains treatment $(3.90 \mathrm{mg} / 100 \mathrm{~g})$ in comparable with the control $(0.95 \mathrm{mg} / 100 \mathrm{~g})$ that crucial for memory. 3- The highest concentration of the Ellagic phenol was recorded with pollen grains treatment $(9.55 \mathrm{mg} / 100 \mathrm{~g})$. 4- Ferulic phenol recorded higher concentration only with Brewer's Yeast treatment $(1.31 \mathrm{mg} / 100 \mathrm{~g})$. 5- Higher density of the (RJ) secretion inside the secret vesicles lobules with Date palm pollen followed with Brewer's Yeast treatments was detected. This paper summary to produce high quality royal jelly one must consider food technology for honeybee colonies in feed diets.
\end{abstract}

\section{INTRODUCTION}

Royal jelly (RJ) mainly is a secreted by the hypopharyngeal gland between the sixth and twelve days of honey bees their life. Additional to another of the mandibular glands. RJ is a complex compound contains many components such as proteins, amino acids, vitamins, sugars, and fats which are essential for development of honey bee members (Fabio et al., 2012). A lot of pharmacological activities on the antibacterial, anti-allergic and anti-aging were studied (Park et al., 2012). RJ improve lipoprotein metabolism and reduce serum total cholesterol in the human healthy (Gugo et al., 2007). Diseases and parasites infected honey bee colonies are 
considered as one of the most important factors affects on the qualitative and quantitative of Royal jelly properties. Presence a royal jelly from different knowing and unknowing sources with significant differences in their components consider a trouble affair, particularly those exported from abroad with lower quality. In another side the beekeepers in Egypt used the supplemental protein diets to feeding bee colonies without completely studies their side effects on the RJ characters. Amino acid could be a good indicator of the origin the RJ. Most of the active substances within royal jelly lead to its natural properties are still unknown (Schönleben et al., 2007). Therefore, this research is interested to study role of some supplements nutrition process in honey bee colonies (Apis mellifera L.) in improved properties of the hypopharyngeal glandular secretion.

\section{MATERIALS AND METHODS}

This work was carried out at the Apiculture Dept., Plant Protection Institute, Agriculture Research Center during late summer season, 2015. Fifteen of honey bee colonies equal in their population density were selected for this study. They were divided into five groups. Each group was offered one of the following feeding processes:

Diets (1) consist of ( $80 \%$ sugar powder $+20 \%$ water) for the control.

Diet (2) consist of ( $30 \%$ Brewer's yeast $+50 \%$ sugar powder $+20 \%$ water).

Diet (3) consist of ( $30 \%$ Soybean flour $+50 \%$ sugar powder $+20 \%$ water).

Diet $(4)$ consist of ( $30 \%$ Pollen grains $+50 \%$ sugar powder $+20 \%$ water).

Diet (5) consist of ( $30 \%$ Date palm pollen (Phoenix dactylifera) $+50 \%$ sugar powder $+20 \%$ water).

$100 \mathrm{~g}$ of each the previously all tested diets were fed by patties that directly placed over the brood nest of tested honeybee colonies two /weekly intervals for one month.

\section{I-Royal Jelly phenol Analysis}

Artificially queen rearing of the tested honey bee colonies was done for each group. Royal jelly was collected at the $3^{\text {rd }}$ day of queen larvae old then kept at $-18^{\circ}$ tell used. High Performance Liquid Chromatography (HPLC) was used to determine the phenol compounds of the tested royal jelly based on the method of Oszmianski and Lee, (1990).

\section{II- Histological studies}

Histological studies of hypopharyngeal glands of honey bee workers were maintained in the laboratory of Pathology Department, Faculty of Veterinary Medicine Beni sueif University; Egypt. 
This work was carried out to estimate the internal cellular differences of the hypopharyngeal gland tissue from nursing worker honey bees during naturally queen rearing ten worker honey bees were collected on the queen cells of each the tested honey bee colonies represented different supplemental protein nutrition as follows: The samples (ten head of tested worker honey bees/colony treatment) were immediately immersed in the fixative solution. For histological studies the samples were fixed in $10 \%$ formalin solution for $24 \mathrm{~h}$, followed by staining with Haematoxylin \&Eosin. Samples were dehydrated in a standard ethanol series: $70 \%, 80 \%, 90 \%$, $95 \%$, and $100 \% 10 \mathrm{~min}$ for each sample. The glands were cleared in histoclear "xylene" for $2 \mathrm{~h}$. All previous processes were carried out by using rotary tissue processor (Leica TP 1020), then were impregnated by placing the samples in 1:1 histoclear "xylene": wax for $1 \mathrm{~h}$ in the incubator at $60{ }^{\circ} \mathrm{C}$ followed by three changes embedding in pure paraffin wax for $45 \mathrm{~min}, 1 \mathrm{~h}$ and $3 \mathrm{~h}$, respectively at $60^{\circ} \mathrm{C}$. The tissue was embedding console system (Leica EG $1150 \mathrm{H}$ ). The blocks were cut into 4 $\mu \mathrm{m}$. Thickness using automatic rotary microtome (Leica RM 2255, Germany).The sections were mounted on chemically clean glass slides without using any adhesive material. For studying general structure of the developmental of hypopharyngeal glands of honeybee workers in sections, the haematoxylin and eosin stains were prepared and used as described by (Drury and Wallington 1980) and (Bancroft and Gamble 2002).

\section{RESULTS AND DISCUSSION}

\section{I- Royal jelly phenol analysis}

HPLC analysis in the tested Royal jelly detected the following phenols; Benzoic, Ellagic, Caffeine, Ferulic, Cinnamic, Caffeic and Rutin as $(\mathrm{mg} / 100 \mathrm{~g})$ of all tested samples.

\section{1- Benzoic phenol}

Benzoic phenol is found in both naturally as an antimicrobial agent and as an added preservative in processed food. The high exposures to it can be poisonous and showed different degrees of the toxicity. Extreme toxicity in some animals was due to degenerative changes in liver, kidney and lungs. People at highest risk from exposure to benzoic acid include patients with liver disease. Toxic symptoms include diarrhea muscular weakness. In human benzoic acid is slightly affects on the skin and irritation to the eye (0.2-0.7 percent) with dose $10 \mathrm{mg}$ or up to $100 \mathrm{mg} /$ day/Five days. Lower doses used to treatment the patients with hyper ammonaemia affects urea cycle 
enzymes to helps nitrogen excretion. Benzoic acid exerts strong antimicrobial effects in the gastrointestinal tract of some animal (Kluge et al.,2006).

It could be concluded that food of lower doses of the Benzoic phenol benefit people suffering of healthy problems as nitrogen mal-excretion. So, RJ from treated honey bee colonies by the tested supplemental nutrition let to reduce the Benzoic acid concentrations particularly with the Date Palm pollen grains(Phoenix dactylifera) (2.65 $\mathrm{mg} / 100 \mathrm{~g})$ in comparable to control one $(6.88 \mathrm{mg} / 100 \mathrm{~g})$ and lower than other tested phenols as shown in Table (1).

\section{2- Ellagic phenol}

Ellagic phenol is a naturally occurring plant polyphenols that exhibits antioxidative properties both in vivo and in vitro. Recently dietary polyphenols are increasing attention as potential protectors against a variety of human diseases like cancer and chemotherapy induced toxicity in animal models. Ellagic acid decreased effect of the Malondidehyde (MDA) resulted of Aluminum residue in food pollution. It also improved Glutatione (GSH) and Gluatathione peroxidase (GSHPX) in animal liver (Özkaya et al.,2010).

Analysis of the RJ revealed presence a Ellagic phenols in all tested foods except of Soybean flour. Pollen grains treatment recorded the highest concentration of it $(9.55 \mathrm{mg} / 100 \mathrm{~g})$ than control $(3.54 \mathrm{mg} / 100 \mathrm{~g})$ and higher than others. That may be decreasing the harmful effects of the pollution in the preserving food and other harmful effects.

\section{3- Caffeine phenol}

Methylxanthine caffeine present in many common beverages during more extensively consumed by the world population. Beside a stimulate effect on the heart respiratory system and numerous behavioral effects. Moderate doses of it induce behavioral stimulant effects that suggest Central nervous system (CNS) stimulation but higher doses can suppress behavioral activity and even performances associated with learning and memory.

$\mathrm{RJ}$ analysis revealed presence a higher concentration of the Caffeine with the Pollen grains treatment $(3.90 \mathrm{mg} / 100 \mathrm{~g})$ in comparable with the control $(0.95 \mathrm{mg} / 100 \mathrm{~g})$ and higher than others as shown in Table (1). That may be causes higher activity of the respiration system or behavior effects in the consumers. Braz, (2002), reported that Caffeine acid improved memory retention at the doses $(0.3-10 \mathrm{mg} / \mathrm{kg})$ of some animals. 


\section{4- Ferulic phenol}

Ferulic (FA) is a hydroxycinnamic acid classified as a phenolic compound. It protects plants from attack of microorganisms and provides antioxidant properties for animals. FA is a phenolic compound with anabolic effects (Crus et al., 2014). Lower concentration of it was recorded with Pollen grains treatment $(0.95 \mathrm{mg} / 100 \mathrm{~g})$, While the higher concentration was detected with Brewer's Yeast treatment $(1.31 \mathrm{mg} / 100 \mathrm{gm})$.

\section{5-Cinnamic phenol}

Cinnamic phenol is a widely distributed phenyl propound component naturally occurring in plants and is mainly found in Cinnamomum cassia BLUME and Panax ginseng. Cinnamic acid was recently reported to exert a tyrosinase inhibitory effect. Treatment with $100 \mathrm{ppm}$ of cinnamic acid resulted in a significant reduction of melanin production and reduce tyrosinase expression. It exhibited depigmenting activity on the UV-B- induced hyperpigmentation of brown guinea pig skin. It may be act as a skin whitening agent via inhibition of tyrosinase activity and expression within melanocytes (Lui et al., 2006). Analyses of the RJ recorded the highest concentration of Cinnamic phenol particularly with the Pollen grains $(2.94 \mathrm{mg} / 100 \mathrm{~g}$ than control $1.36 \mathrm{mg} / 100 \mathrm{~g})$.

\section{6- Caffeic and Rutin Phenols.}

Limit detection of Caffeic and Rutin phenols was $0.3 \mu \mathrm{g} / \mathrm{ml}$.

From the results obtained it could be concluded that RJ secretion after feeding honey bee colonies by Date palm (Phoenix dactylifera) treatment recorded the lowest concentration of the benzoic phenol benefit in public health. While pollen grains treatment recorded the higher values of the Caffeine phenol can be effects on the behavioral stimulant of CNS than the lower doses, also it recorded higher concentration of the Ellagic phenol higher than others. The highest concentration of the Cinnamic phenol was detected with the Pollen grains. While the higher concentration of Ferulic phenol was higher with Brewer's Yeast treatment.

Table 1. Phenolic concentrations of the Royal jelly $(\mathrm{mg} / 100 \mathrm{~g})$ at different feeding treatments.

\begin{tabular}{|l|c|c|c|c|c|c|c|}
\hline Item & Benzoic & Ellagic & Caffeine & Ferulic & Cinnamic & Caffeic & Rutin \\
\hline Control & 6.88 & 3.54 & 0.95 & 1.28 & 1.36 & $<\mathrm{LOQ}$ & $<\mathrm{LOQ}$ \\
\hline Brewer's yeast & 3.31 & 3.64 & 2.64 & 1.31 & 1.83 & $<\mathrm{LOQ}$ & $<\mathrm{LOQ}$ \\
\hline Soybean flour & 3.68 & $\mathrm{ND}$ & 1.99 & 1.05 & 1.66 & $<\mathrm{LOQ}$ & $<\mathrm{LOQ}$ \\
\hline Pollen grains & 4.75 & 9.55 & 3.90 & 0.59 & 2.94 & $<\mathrm{LOQ}$ & $<\mathrm{LOQ}$ \\
\hline Date Palm pollen & 2.65 & 3.49 & 1.20 & 0.82 & 1.23 & $<\mathrm{LOQ}$ & $<\mathrm{LOQ}$ \\
\hline
\end{tabular}

ND: Not determined. 


\section{II--Histological studies}

Hypopharyngeal gland of the honey bee workers in non treated and treated honey bee colonies by tested the supplemental protein nutrition were dissected out to clarify their effect on the glandular structure tissue particularly secrete vesicle globules. There was a crowded in the glandular lobules with the Brewer' yeast (Fig.2) than those recorded with control one (Fig.1) and other glandular lobules (Figs.3,4,5). The secrete vesicles lobules showed the little secretion and higher vacuoles with control and with Soybean flour treatment (Figs.6,7,8). Whereas with Date palm pollen treatment the higher density secretion of the (RJ) was detected (Fig.10) followed with pollen grains treatment (Fig.9).

From all results obtained it could be concluded that Date palm pollen treatment indicated improved in the secrete vesicle globules tissue and higher density of the royal jelly secretion than other tested protein nutrition in same time it showed specific properties of the RJ phenol components followed with the pollen grains treatments.

Zohra and Talat, (2008) reported that RJ quality analysis is not related to the glandular lobule size. That agreement with our results whereas the treatment with Brewer's yeast treatment recoded higher lobule size of the Hypopharyngeal gland whereas their secrete vesicle globules showed higher vacuoles and little secretion of the RJ. So, bigger Size of the HG lobules is not reflects on the secretion density or quality. In spite of the hypopharyngeal glandular lobules with Date palm pollen treatment showed moderate size may they showed the higher density of the RJ secretion. That affirm the $(\mathrm{HJ})$ lobule size is not indictor to the quantities secretion of the RJ. Therefore, it must be not depends on the HG lobule size as sign or indicator on the higher secretion or quality of the royal jelly secretion.

Borguini et al., (2012) reported that RJ presented relatively low antioxidant potent. The antioxidant is due to phenolic content, protein and fatty acids. Exposure some animals to electromagnetic fields (EMF) induces harmful effects on testis and reproductive activities. Administration of Date palm pollen before exposure to EMF improved the sperm count, viability, motility and testosterone level and prevent the sperm abnormality (Baharara et al., 2015). Martos et al., (2008) and Kohichi et al, (2014) reported that the biological activates of honey, propolis and Royal jelly are mainly attributed to the phenolic compounds such as flavonoids exhibit a wide range of biological activity including antiviral, anti inflammatory, antiallergic and inhibit oxyenase. Phenolic compounds produce physiological effect beneficial to health. Bees fed sugar syrup alone had lower protein concentrations and smaller hypopharyngeal gland. 
There was a relationship between diet protein levels and immune responses (Hoffman, 2010). Abd El Azim et al., (2015) Identified a six phenols as Caffeic acid, Gallic acid, Coumaric acid, Chlorogenic acid and Quercetin in Date palm pollen (Phoenix dactylifera) (DPP). In addition DPP has been used for long time as a traditional Egyptian herbal medicine for improving male and female fertility. From these results it could be advice to use Date Palm Pollen (Phoenix dactylifera) to improving properties of the hypopharyngeal glandular secretion.
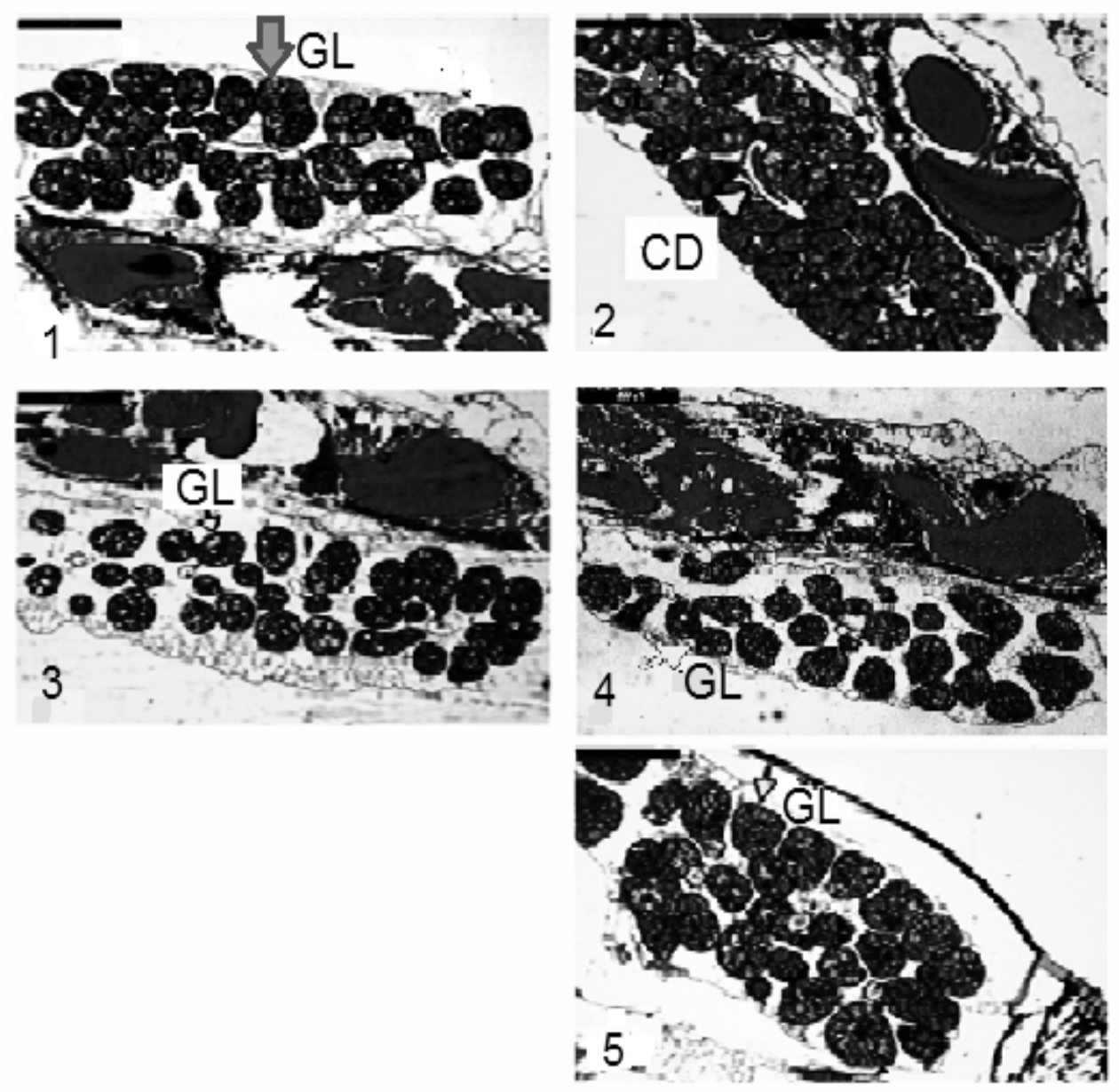

Fig.1: Hypopharyngeal gland lobules as control.

Fig.2: Same in treated with Brewer's yeast.

Fig.3: Same in treated with Soybean flour.

Fig.4: Same with pollen grains treatment.

Fig.5:Same with Date palm pollen treatment.

CD : Common duct. GL: Glandular lobules.

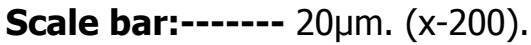



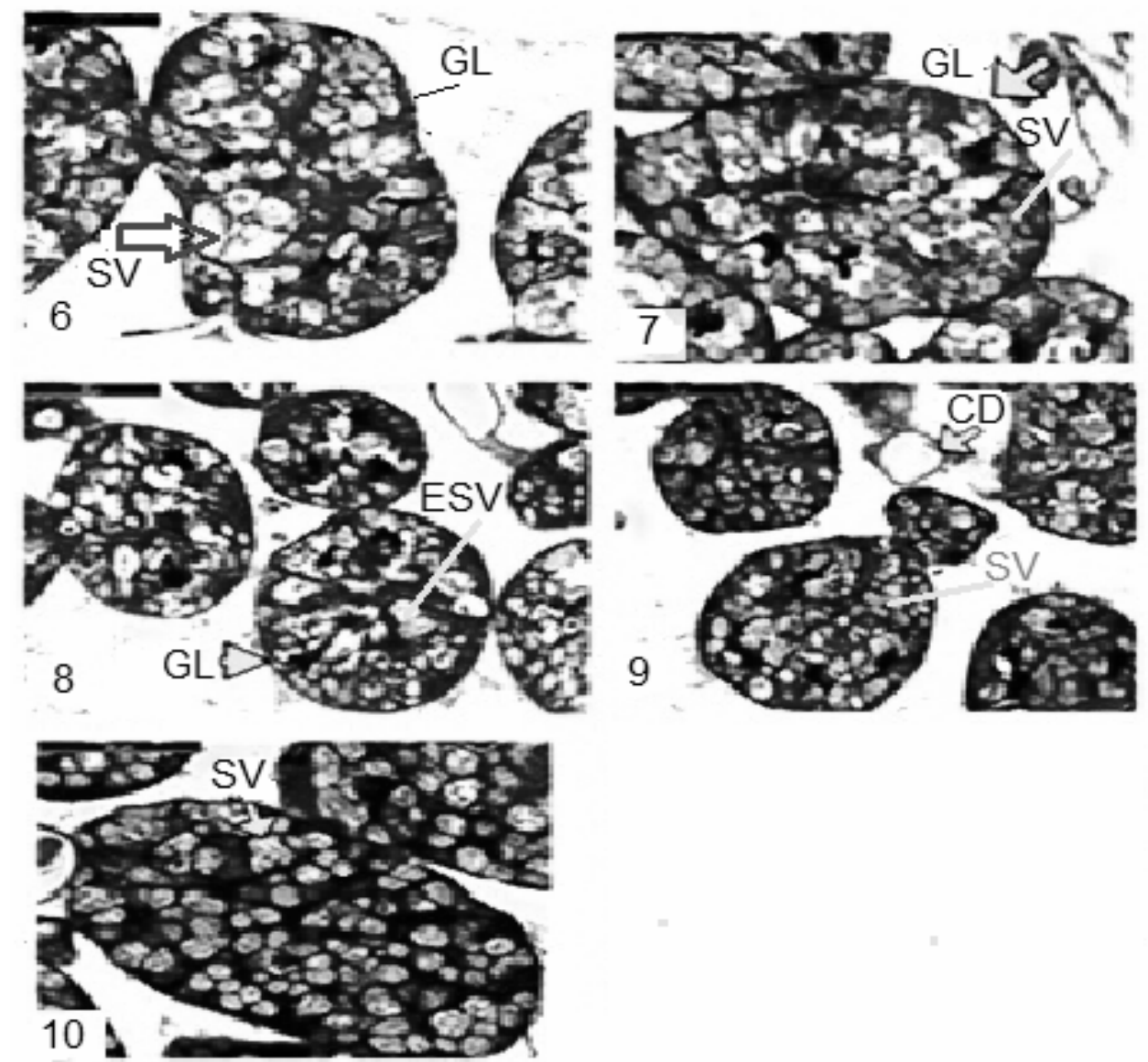

Fig.6: Glandular lobule of the HG as control.

Fig.7: Same in treated with Brewer's yeast.

Fig.8: Same in treated with Soybean flour

Fig.9: Same with pollen grains treatment.

Fig.10: Same with Date palm pollen treatment.

CD: Common duct.

GL: Hypopharyngeal Glandular lobule.

SV: Secrete vesicle globule. ESV: Empty secrete vesicle globule.

Scale bar: $50 \mu \mathrm{m}-(\mathrm{x}-400)$. 


\section{REFERENCES}

1. Abd El Azim, M.H.M. Amani M.D. El Mesalamy, F.A.Yassin and S.A.Khalil, 2015. Identification phenolic and biological activities of methanolic extract of Date palm pollen (Phoenix dactylifera). J. Microb Biochem Technol. Vol,7(1):047-050.

2. Baharara, J.; E.Amini; F.S.Abdollahi; N.Nikdeland and M.A. Samani. 2015. Protective effect of date palm pollen (Phoenix dactylifera) on sperm parameters and electromagnetic field(50Hz). J HerbMed Pharmacol., 4(3):75-80.

3. Bancroft, G.D. and M. Gamble. 2002. Theory and practice of histological techniques. Churchill Livingstone; London, Fifth Edition.

4. Borguini,R.G.; F.Duarte; M.L.T.Alves and T. E. Weinstein,2012.Evaluation of the antioxidant potential of Royal jelly during storage. Jourlib J. ISSN: 2333-9721.

5. Braz, J M B R.,2002. Effects of caffeine on learning and memory in rats tested in the morris water maze. Brazilian. J. Medical \& Biol. Res.,Vol.35(10): 1201-1208.

6. Crus, Z. U.M.; S.Perard; R.Vicente; F.D.Alvare; N.G.Torrent Olivera;H.G. Rios; A.S.Navarro; R.Rojo; C.A. M.Herre and L. A. Reyes,2014. Effects of free Ferulic acid on productive performance, blood Metabolites and carcass characteristics of feedlot finishing ewe lambs. J. Animal Sci., Vol.92 No.12:5762-68.

7. Drury R.A. and E.A. Wallington 1980. Craletons histological technique. Oxford University Press; London, Fifth Edition.

8. Fabio de Assis P.; R. O. de Fernandes; J. Poderoso; W. C. Santana and D. Message, 2012. Nutritional and temporal effects on hypopharyngeal glandes of Africanized honeybees (Hymenoptera - Apidae). Sociobiol,59 (2):447-456.

9. Gugo, H.; A.Saige; M. Sato; I. Miyazawa; M. Shibata; Y. Takahata and F. Morimatsu, 2007.Royal jelly supplementation improves lipoprotein metabolism in humans. J. Nutr. Sci. Vitamiinol(Tokyo) 53(4):345-348.

10. Hoffman G. De G.,2010. The effect of diet on protein concentration hypopharyngeal gland development and virus load in worker honey bee (Apis mellifera L.). J. Insect physiol.,56:1184-1191.

11. Kluge, H.; J. Broz and K. Eder, 2006. Effect of benzoic on growth performancd, nutritient digestibility, nitrogen balance, gastrointestinal microflora and parameters of microbial metabolism in piglets. J Anim. Phsiol. Anim. Nutr (Bert).90(7-8):316-24.

12. Kohichi Y; Y. Kogashiwa; Y. Moro, and N. Kohno, 2014. The Effect of Topical Application of Royal Jelly on Chemoradiotherapy-Induced Mucositis in Head and Neck Cancer: A Preliminary Study. Intern. J. Otolaryngol. Article ID: 974967, 5 pages. 
13. Liu L.; W. R.Hudgins; S.Shack; MU.Q. Yin and D.Samid, 2006.Cinnamic acid:A natural product with potential use in cancer intervention. International J. Cancer, vol.62.Issue 3: 345-350.

14. Martos,V.U.; R.Navajas; F.Lopez and P.A. Alvarez,2008.Functional properties of honey propolis and royal jelly, J. Food Sci.73(9): 117-24.

15. Oszmianski, J. and C. Y. Lee. 1990. Isolation and HPLC determination of phenolic compounds in red grapes. Am. J. Enol. Vitic., 41:3:204- 206.

16. Özkaya A.; S. Çelik; A. YÜCE; Z.Sahin and Ö.Yilmaz,2010. The effects of Ellagic acid on some oxidative stress induced by Aluminum. Kafkas Univ., Vet Fak Derg, 16(2): 263-268.

17. Park, HM.; Mh.Cho; Y.Cho and Sy Kim, 2012. Royal jelly increases collagen production in rat skin after ovariectomy. J. Med. Food (6):568- 575.

18. Schönleben,S; A. Sickmonn ; M.J.Mueller and J.Reinders,2007. Proteome analysis of Apis mellifera royal jelly. Analytical and Bioandytical chemistry, Vol., 389,Issue 4: 1087-1093.

19. Zohra, A. and M.Talat, 2008. Impact of pollens supplements and vitamins of the development of hypopharyngeal glands and on brood area in honey bees. J. Aic. Sci., Vol.,52-No.2:1-12. 


\section{فاعلية بعض نظم التغذية البروتينية لطوائف نحل العسل}

\section{فى تحسين خصائص الإفراز الغذى لغدة الغذاء الملكى}

$$
\begin{aligned}
& \text { محمود عزت زكريا' - نجلاء الأحمدى غزالة ' - مباء }
\end{aligned}
$$

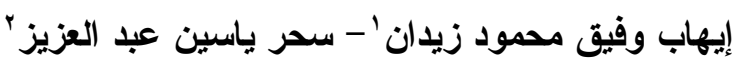

$$
\begin{aligned}
& \text { ا ـ قسم بحوث النحل - معهد بحوث وقاية النباتات- مركز البحوث الزراعية - الدقى- الجبزة. } \\
& \text { r ـ ق. قسم الحشرات الإقتصادية والمبيدات -كلبة الزراعة جامعة القاهرة. }
\end{aligned}
$$

ترجع جودة الغذاء الملكى الى الحالة الفسيولوجية لغدد الغذاء الملكى فى شغالات نحل العسل

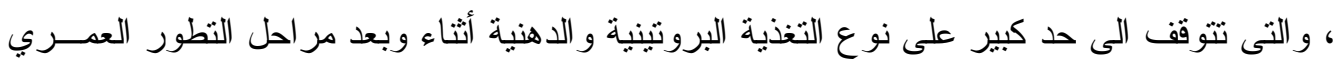

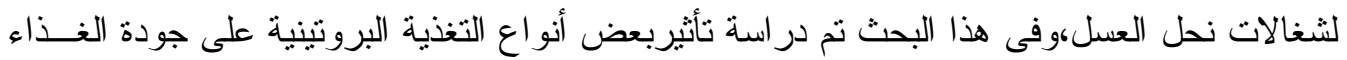

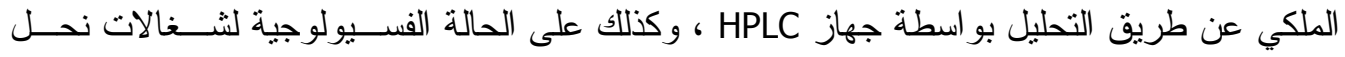

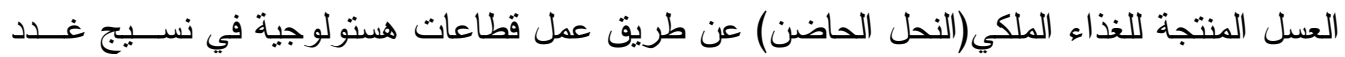

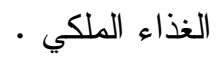

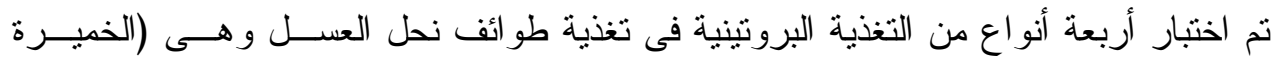
الجافة، دقيق فول الصويا ، حبوب اللقاح و طلع النخيل) بالاضافة الى معاملة المقارنة .

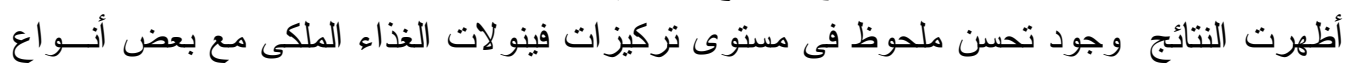
نظم التغذية البروتينية:-

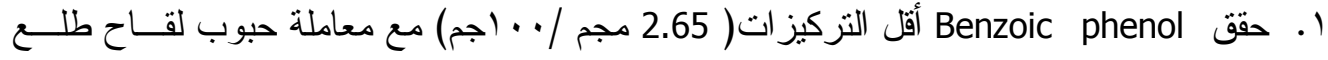

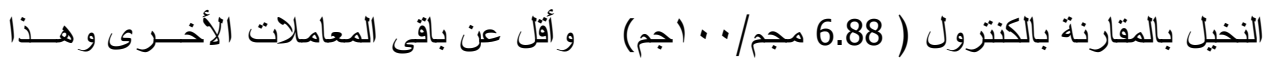
الخفض مهم للصحة العامة.

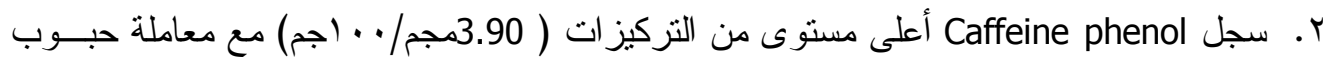

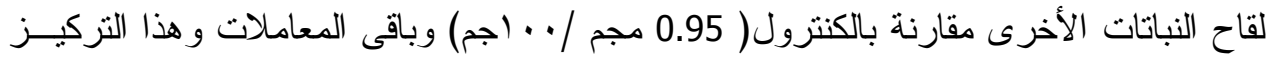

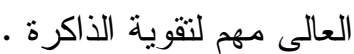

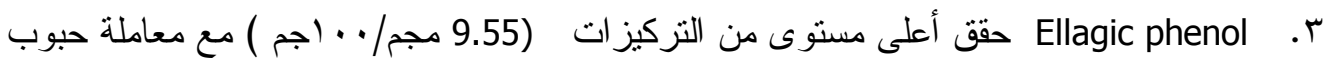
اللقاح أيضا و أعلى عن الكنترول (3.54مج/ · · · اجم ) وباقى المعاملات كذللك.

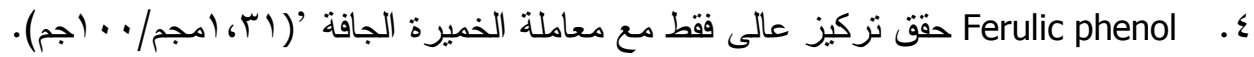

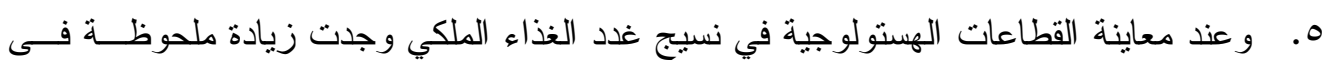

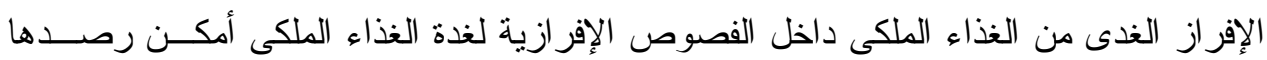

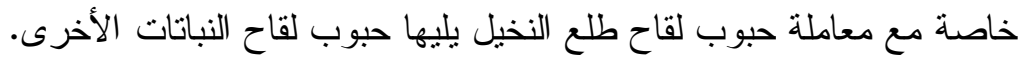

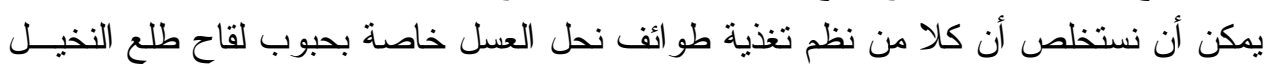

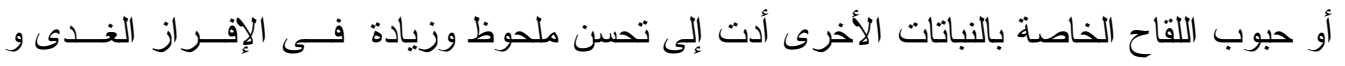

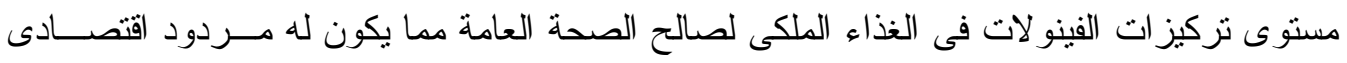

